\title{
PENGARUH AIR LAUT TERHADAP SIFAT LISTRIK ZEOLIT SINTETIS DARI BOTTOM ASH MELALUI PROSES ALKALI HIDROTERMAL
}

\author{
Tiya Lestari, Afdhal Muttaqin \\ Jurusan Fisika FMIPA Universitas Andalas, Padang \\ Kampus Unand Limau Manis, Pauh, Padang 25163 \\ e-mail: yaztar9@yahoo.com
}

\begin{abstract}
ABSTRAK
Telah dilakukan sintesis zeolit berbahan dasar bottom ash dan $\mathrm{NaOH}$ sebagai aktivator dengan perbandingan 1 : 1,2 g. Sebagai media kristalisasi dalam proses pembentukan kristal zeolit, digunakan air laut dan akuades melalui proses alkali hidrotermal. Proses alkali hidrotermal dilakukan menggunakan teflon autoclave yang dipanaskan di dalam oven pada temperatur $100^{\circ} \mathrm{C}$ selama 6 jam. Zeolit sintetis yang didapatkan kemudian diuji secara kualitatif dan kuantitatif dengan menggunakan XRD dan SEM-EDS serta penentuan konduktivitas listrik menggunakan LCR-meter model TH2820. Hasil analisis pola XRD menunjukkan bahwa sampel mengandung zeolit Na-X, zeolit Na-P, hidroksisodalit, dan kuarsa. Hasil SEM-EDS memperlihatkan pengaruh perbedaan media kristalisasi terhadap permukaan zeolit yang dihasilkan. Zeolit dengan kemurnian yang baik berbentuk kubik didapatkan pada sampel yang menggunakan media kristalisasi air laut dari tepi pantai dengan kadar kuarsa yang lebih rendah. Dari nilai konduktivitas listriknya diketahui bahwa sampel berada dalam rentang bahan semikonduktor. Nilai dengan konduktivitas listrik tertinggi terdapat pada sampel yang menggunakan media kristalisasi air laut di tepi pantai dengan nilai konduktivitas $1,287 \times 10^{-6}-3,040 \times 10^{-6} \mathrm{~S} / \mathrm{cm}$.
\end{abstract}

Kata kunci : zeolit, bottom ash, kristalisasi, proses alkali hidrotermal, konduktivitas listrik

\section{PENDAHULUAN}

Zeolit merupakan mineral kristal alumina silika tetrahedral berpori yang mempunyai struktur kerangka tiga dimensi. Struktur kerangka tiga dimensi menjadikan zeolit sebagai material berpori dengan ukuran pori berkisar antara $0,3 \mathrm{~nm}$ hingga $1,5 \mathrm{~nm}$ dan tergolong dalam material nanopori pada bagian mikropori dengan ukuran pori kecil dari $2 \mathrm{~nm}$ (IUPAC). Dengan pori yang dimilikinya, zeolit dapat dimanfaatkan antara lain sebagai adsorben, penukar ion (ion exchange), water treatment, paper manufacturing, dan katalis (Aurbach, 2003; Yang, 2003).

Sintesis zeolit berbahan dasar limbah banyak dikembangkan dewasa ini untuk berbagai keperluan dan aplikasi (Kalogeras dan Dova , 1998; Ertugrul dan Alime, 2007; Widiawati, 2005; Sholichah,dkk., 2013). Berbagai metode dan bahan dasar yang digunakan berhasil memperoleh zeolit dengan tipe yang berbeda (Jumaeri dan Lestari, 2007; Sunardi, dkk., 2007; Anggoro, dkk., 2007; Trivana, 2013). Tipe zeolit yang berbeda tentu saja menghasilkan zeolit dengan sifat listrik yang berbeda juga yang dapat dimanfaatkan pada berbagai aplikasi elektronika (Kalogeras dan Dova, 1998; Yang, 2003: Ertugrul dan Alime, 2007; Li dan Dutta, 2010).

Salah satu metode yang dikembangkan dan terbukti dapat menghasilkan zeolit dari senyawa senyawa kuarsa dan mullit adalah metode hidrotermal. Metode ini dikembangkan dengan mengacu pada proses pembentukan zeolit di alam. Tahapan yang digunakan pada metode ini disesuaikan dengan proses yang dialami oleh zeolit alam saat mulai terbentuknya (Sunardi, dkk., 2007; Belviso, 2009; Londar, 2010; Yu, dkk., 2014). 
Penambahan logam alkali $(\mathrm{NaOH})$ serta air laut pada proses alkali hidrotermal memberikan peranan penting untuk pembentukan kristal zeolit serta memberikan hasil zeolit dengan tingkat kristalisasi yang baik (Belviso, 2009). Hal ini karena kandungan mineral pada air laut berhasil ditambahkan sehingga $\mathrm{NaOH}$ dan mineral dalam air laut berfungsi membentuk ikatan baru dan mengkonversi mineral kuarsa dan mullit menjadi mineral zeolit berbagai jenis. Berbeda halnya jika hanya ditambahkan akuades dan $\mathrm{NaOH}$ pada proses hidrotermal, yang tentu saja menjadikan kandungan mineral lebih rendah dalam proses pembentukan zeolit kurang maksimal sehingga fase kuarsa dan mullit pada bahan dasar tidak berhasil dikonversi menjadi zeolit secara signifikan (Fatiha, 2013). Unsur $\mathrm{Na}$, baik yang terdapat pada senyawa $\mathrm{NaOH}$ maupun yang terdapat pada air laut merupakan pemicu pengaturan struktur zeolit. Sifat zeolit sebagai material dengan struktur berpori, biasanya diisi oleh air dan kation yang dapat dipertukarkan (Yu, dkk., 2014)

\section{METODE}

\subsection{Sintesis Zeolit}

Bahan dasar yang digunakan pada sintesis zeolit yaitu bottom ash dengan metode mengacu pada penelitian $\mathrm{Yu}$, dkk (2014). Bottom ash dicampur dengan $\mathrm{NaOH}$ bubuk dengan perbandingan 1:1,2 g. Dengan menggunakan cawan pemanas, sampel yang telah dicampur merata dimasukkan ke dalam furnace dengan temperatur $550^{\circ} \mathrm{C}$ selama 2 jam. Hasil berupa padatan kemudian didinginkan dan digiling. Selanjutnya, setiap $16 \mathrm{~g}$ dari campuran tersebut dicampurkan dengan $80 \mathrm{ml}$ air laut dan diaduk menggunakan magnetic stirrer selama 24 jam. Selanjutnya, larutan dimasukkan ke dalam teflon autoclave yang kemudian dipanaskan menggunakan oven pada temperatur $100^{\circ} \mathrm{C}$ selama 6 jam. Bubuk sampel yang telah mengalami proses alkali hidrotermal dicuci dengan menggunakan akuades hingga didapatkan $\mathrm{pH}$ netral. Setelah itu, untuk menghilangkan kandungan air yang terdapat pada bubuk sampel, sampel dipanaskan pada temperatur $80^{\circ} \mathrm{C}$ selama 12 jam dengan menggunakan oven. Hasil zeolit sintetis yang berbentuk bubuk disimpan pada wadah kedap udara sebelum dikarakterisasi dan dikompaksi.

\subsection{Karakterisasi dan Penentuan Sifat listrik Zeolit Sintetis}

Kristalinitas, komposisi dan jenis zeolit yang terbentuk akan di karakterisasi dengan menggunakan XRD, sedangkan struktur permukaan serta komposisi unsur yang terdapat pada zeolit sintetis dikarakterisasi menggunakan SEM-EDS. Untuk penentuan sifat listrik zeolit sintetis, zeolit bubuk dikompaksi berbentuk tablet terlebih dahulu dengan diameter $12,45 \mathrm{~mm}$ dan ketebalan pada rentang 1,3-1,4 mm. Setelah selesai dikompaksi, kedua sisi zeolit kompaksi dilapisi dengan elektroda aluminium stainless steel dan dijepitkan pada alat LCR-meter model TH2820 untuk menentukan nilai konduktivitas listrik.

\section{HASIL DAN DISKUSI}

\subsection{Kristalinitas, Komposisi, dan jenis Zeolit Sintetis}

Puncak difraksi yang didapatkan dari data pengukuran dicocokkan dengan standar difraksi sinar-X yaitu Joint Commited on Powder Difraction Standards (JCPDS). Pada Gambar 1 terlihat bahwa proses yang dilakukan telah berhasil menumbuhkan zeolit $\mathrm{Na}-\mathrm{X}$ dan zeolit Na-P. Zeolit Na-X merupakan zeolit dengan struktur kubik sedangkan zeolit Na-P memiliki struktur tetragonal.

Gambar 1(a) sampel A1T merupakan hasil sintesis zeolit dari bottom ash menggunakan $\mathrm{NaOH}$ serta akuades sebagai media kristalisasi. Jika dibandingkan dengan bottom ash dengan unsur pendukung utama kuarsa (unsur silika $\left(\mathrm{SiO}_{2}\right)$ ) dan mullit (alumina $\left.\left(\mathrm{Al}_{6} \mathrm{Si}_{2} \mathrm{O}_{13}\right)\right)$ (Yunica, 2013), proses alkali hidrotermal yang dilakukan berhasil mengubah 
struktur kuarsa dan mullit sebagai struktur dasar pada bottom ash menjadi struktur zeolit sintetis.

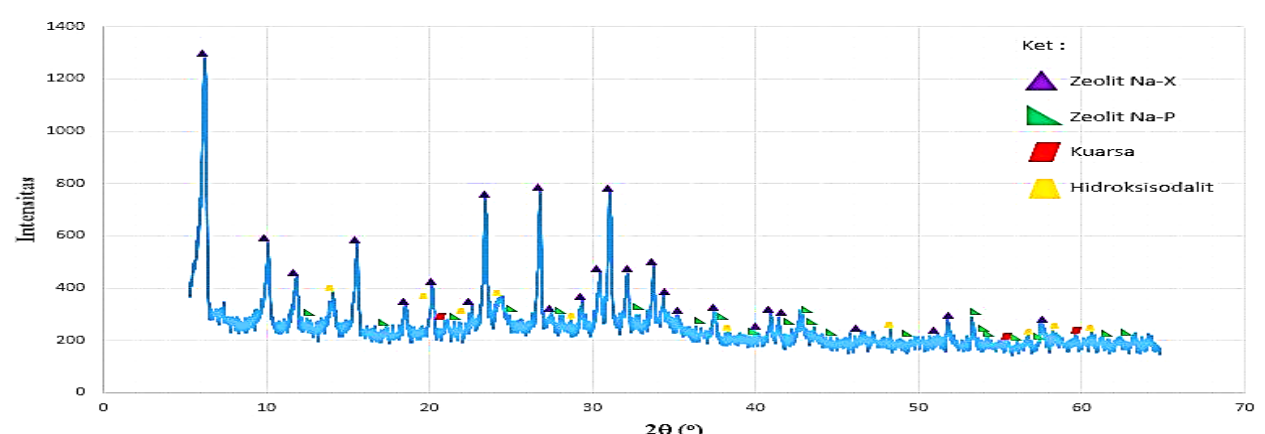

(a)

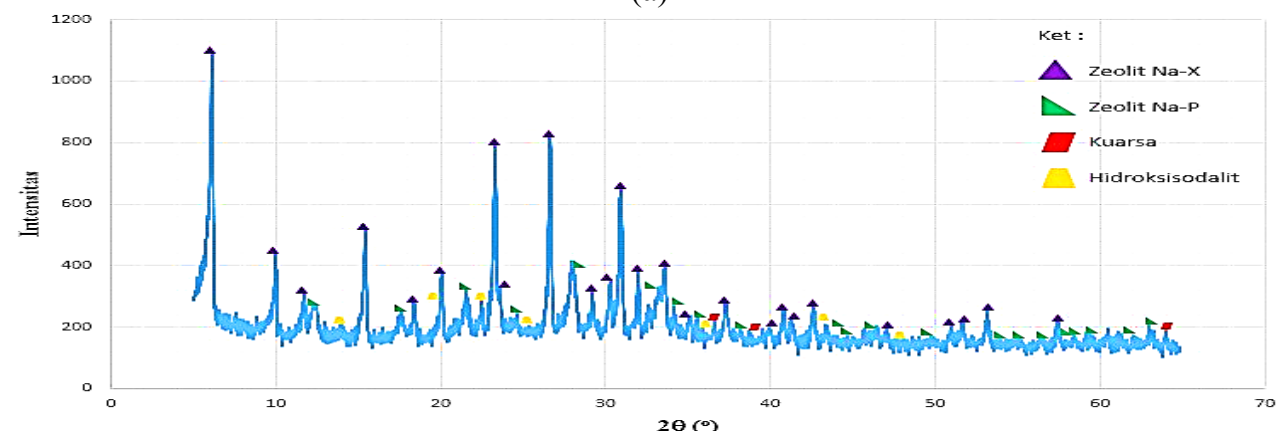

(b)

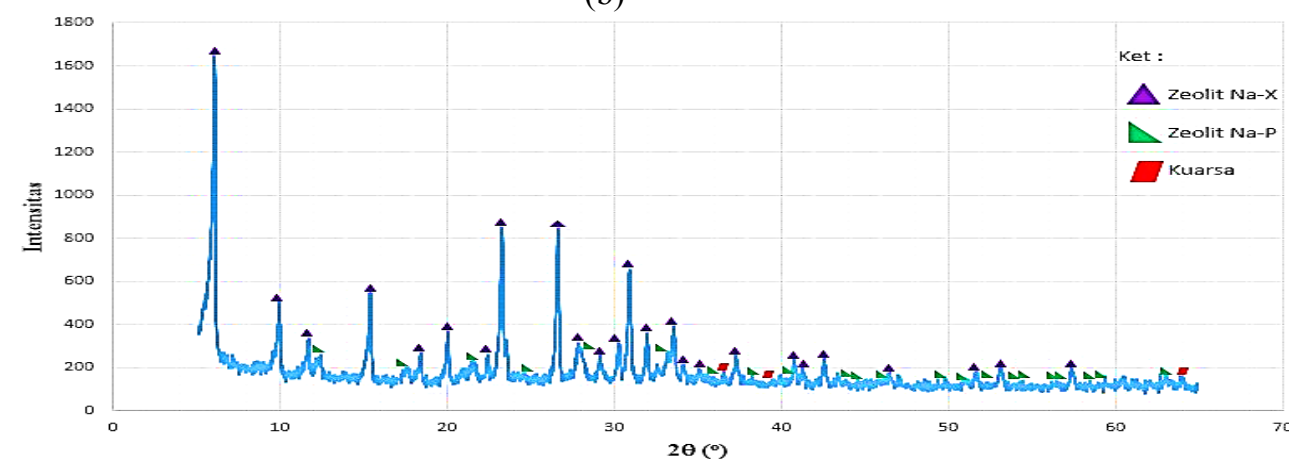

(c)

Gambar 1 Hasil XRD zeolit sintetis (a) A1T dengan media kristalisasi air laut dari tepi pantai Padang, (b) A2T dengan media kristalisasi air laut dari muara Padang, dan (c) A3T dengan media kristalisasi akuades melalui proses akali hidrotermal

Setelah dibandingkan dengan data JCPDS, dapat dilihat bahwa untuk jenis zeolit yang terbentuk yaitu zeolit Na-X dan zeolit Na-P. Selain zeolit, masih terdapat sisa kuarsa serta hasil lain berupa hidroksisodalit, kecuali pada sampel A3T yang tidak memiliki puncak hidroksisodalit. Zeolit yang dominan terbentuk yaitu zeolit Na-X dengan puncak tertinggi yang dimilikinya yaitu pada $2 \theta=6,270^{\circ}$ (JCPDS 38-0237) serta terdapat juga zeolit Na-P (JCPDS 44-0052). Terbukti bahwa penggunaan akuades tidak menghasilkan kristalinitas yang lebih baik, dibandingkan pada penggunaan air laut, walaupun telah menghasilkan zeolit dengan tipe yang sama. Selain itu, pada penggunaan akuades masih terdapat hidroksisodalit (JCPDS 11-0401) dan kuarsa (JCPDS 46-1045) yang merupakan penyusun utama bottom ash, yang tentu saja mengurangi tingkat kemurnian dari zeolit yang dihasilkan.

Jika dibandingkan dengan Gambar 1(b) yang merupakan sampel A2T, walaupun terbentuk zeolit yang sama dengan sampel A1T (zeolit Na-X dan zeolit Na-P), akan tetapi 
didapatkan puncak-puncak zeolit dengan intensitas yang lebih tinggi. Selain itu, fase kuarsa dan hidroksisodalit menjadi lebih rendah dibandingkan dengan sampel A1T. Posisi zeolit $\mathrm{Na}-\mathrm{X}$ yang lebih dominan terutama ditunjukkan dari puncak tertinggi pada $2 \theta=$ $6,12^{\circ}$ (JCPDS 38-0237) Selain zeolit Na-X, intensitas puncak untuk zeolit Na-P (JCPDS 44-0052) mengalami peningkatan. Sampel A2T adalah sampel dengan proses yang sama namun berbeda dalam media kristalinitasnya. Sampel A2T menggunakan air laut yang diambil di muara.

Hasil XRD untuk sampel A3T yang merupakan sampel dengan menggunakan air laut dari tepi pantai Padang, dapat dilihat pada Gambar 1(c). Puncak- puncak yang muncul pada sampel A3T tidak jauh berbeda dengan sampel A2T yang juga sama-sama menggunakan air laut sebagai media kristalisasi. Pada sampel A3T terlihat bahwa kristalinitas menjadi lebih baik yang terlihat pada lebih tingginya intensitas spektrum yang dihasilkan dari pantulan posisi atom pada kerangka zeolit. Zeolit Na-X masih menjadi zeolit yang dominan terbentuk dari proses ini dengan hasil sampingan berupa zeolit Na-P dan kuarsa yang masih tersisa dengan intensitas yang lebih rendah jika dibandingkan sampel A1T dan A2T. Puncak tertinggi dari zeolit Na-X dihasilkan pada posisi $2 \theta=6,090^{\circ}$ (JCPDS 38-0237).

Penggunaan air laut berhasil meningkatkan tingkat kemurnian zeolit sintetis. Sampel A3T yang merupakan sampel dengan media kristalisasi air laut dari tepi pantai memberikan peningkatan terhadap kemurnian zeolit dari pada sampel A1T dan A2T karena pada kedua sampel (A1T dan A2T) masih terdapat hidroksisodalit. Namun, dari ketiga sampel masih terdapat kuarsa yang juga merupakan komponen dasar dari bottom ash yang digunakan. Terlihat bahwa kandungan mineral pada air laut belum mampu sepenuhnya mengubah struktur kuarsa untuk dapat berikatan dengan mineral air laut guna menghasilkan zeolit, baik tipe Na-X maupun tipe Na-P.

Hasil yang didapatkan tidak terlepas dari penggunaan $\mathrm{NaOH}$ pada proses hidrotermal. $\mathrm{NaOH}$ serta air laut pada proses alkali hidrotermal memberikan peranan penting untuk pembentukan kristal zeolit serta memberikan hasil zeolit dengan tingkat kristalisasi yang baik (Belviso, 2009). Penggunaan $\mathrm{NaOH}$ dan air laut telah berhasil mengkonversi mineral kuarsa dan mullit yang terdapat pada bottom ash menjadi mineral zeolit. Sedangkan penggunaan akuades pada proses alkali hidrotermal tidak mampu mengurangi fase kuarsa secara signifikan (Fatiha, 2013). Hasil yang diperoleh menunjukkan pengaruh dari berlimpahnya unsur $\mathrm{Na}$, baik yang terdapat pada senyawa $\mathrm{NaOH}$ serta juga terdapat pada air laut sebagai pemicu pengaturan struktur zeolit karena zeolit merupakan struktur berpori yang biasanya diisi oleh air dan kation yang dapat dipertukarkan ( $\mathrm{Yu}$, dkk., 2014). Masih terdapatnya fase kuarsa dimungkinkan karena kurangnya kandungan mineral yang akan mengkonversi kuarsa menjadi zeolit, kurangnya waktu dalam proses hidrotermal maupun temperatur yang belum mencapai temperatur optimal.

\subsection{Struktur Permukaan Zeolit Sintetis}

Karakterisasi SEM dilakukan untuk mengetahui gambaran bentuk permukaan sampel. Sintesis zeolit dengan bahan dasar bottom ash dengan media kristalisasi yang berbeda memberikan perubahan bentuk permukaan setelah diberikan perlakuan hingga menjadi zeolit. Pengaruh pemberian media kristalisasi berupa akuades dan air laut dapat dilihat dari perubahan ukuran serta bentuk permukaan serta homogenitas setiap sampel. Sebagaimana hasil XRD, hasil foto SEM permukaan menunjukkan adanya pengaruh dari air laut pada homogenitas dan ukuran partikel. Secara umum terlihat bahwa sampel A3T memiliki ukuran partikel yang lebih seragam dengan sebaran lebih merata tidak seperti sampel A1T yang masih terdapat bongkahan dengan sebaran yang tidak merata. Struktur permukaan sampel A2T berada di antara sampel A1T dan A3T. Hasil karakterisasi SEM dari bottom ash hingga menjadi zeolit, dapat dilihat pada Gambar 2. 

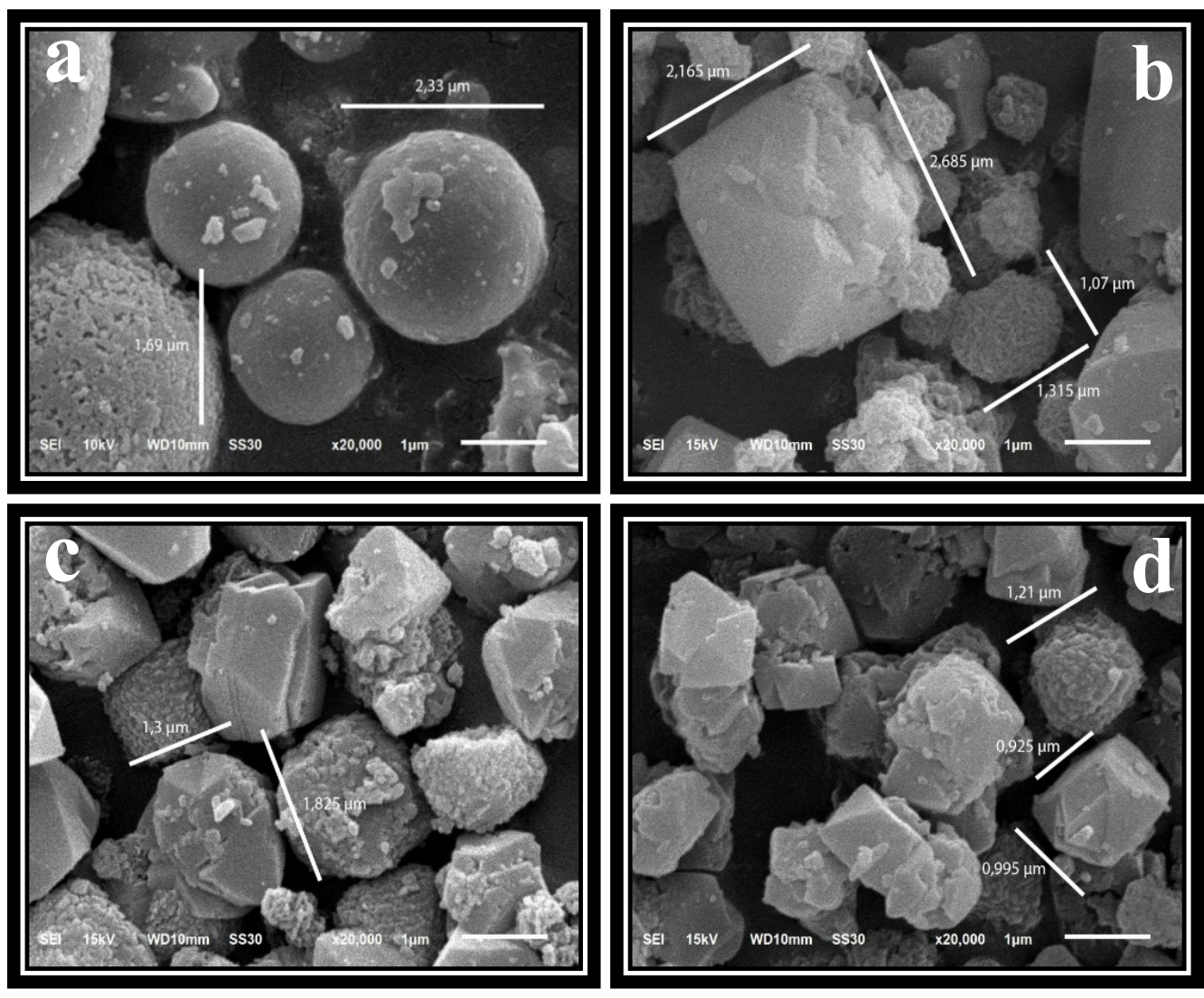

Gambar 2 Hasil SEM (a) bottom ash (b) zeolit sintetis A1T dengan media kristalisasi air laut dari tepi pantai Padang, (c) zeolit sintetis dengan media kristalisasi air laut dari muara Padang, dan (d) zeolit sintetis A3T dengan media kristalisasi akuades melelui proses akali hidrotermal

Jika dilihat dari bottom ash pada Gambar 2(a), bentuk permukaannya berbentuk bulat dengan besar partikel yang tidak merata yang merupakan kuarsa dan mullit. Setelah diberikan perlakukan pada bottom ash, struktur permukaan yang terbentuk menjadi berbentuk kubik serta tetragonal sebagaimana hasil yang ditunjukkan oleh XRD. Dominasi bentuk kubik pada Gambar 2(a), 2(b), dan 2(c) sesuai dengan hasil XRD yang memperlihatkan intensitas utama berasal dari struktur zeolit Na-X. Bentuk struktur lain yang berasal dari zeolit Na-P maupun hidroksisodalit atau kuarsa tidak begitu dominan dan tidak dapat dibedakan sebagaimana hasil XRD yang memperlihatkan puncak-puncak sekunder yang tidak dominan dari struktur ini.

Dilihat dari ukuran partikel zeolit sintetis yang terbentuk, sampel A1T memiliki ukuran kira-kira berkisar $2,165-2,685 \mu \mathrm{m}$, sampel A2T berkisar $1,3-1,825 \mu \mathrm{m}$, sedangkan sampel A3T memiliki ukuran berkisar 0,925 - 1,21 $\mu \mathrm{m}$. dari segi ukuran per partikel, sampel A3T memiliki ukuran rata-rata yang jauh lebih kecil dibandingkan sampel lain. Ini menunjukkan bahwa, selain sampel A3T lebih homogen, ukuran per partikelnya juga menjadi lebih kecil. Air laut dengan kandungan mineral yang lebih tinggi menjadikan zeolit lebih homogen dan lebih kristalin.

\subsection{Perbandingan Komposisi untuk Zeolit Sintetis}

Karakterisasi EDS digunakan untuk mengetahui komposisi unsur-unsur yang terdapat dalam bottom ash dan zeolit sintetis. Data hasil karakterisasi menggunakan EDS dapat dilihat pada Tabel 1. Dari data EDS pada Tabel 1 dapat dilihat dengan jelas pengaruh dari penggunaan air laut dan akuades dalam sintesis zeolit dengan bahan dasar bottom ash 
terhadap komposisi unsur yang terkandung dalam setiap sampel. Komposisi utama dari bottom ash yang berupa unsur $\mathrm{C}, \mathrm{N}$ dan $\mathrm{O}$ merupakan unsur utama dari hasil pembakaran batubara dengan komposisi lebih dari $20 \%$. Sedangkan unsur Si $(13,25 \%)$ dan Al $(8,68$ $\%)$ sebagai unsur utama pembentuk zeolit menjadikan bottom ash sebagai sumber bahan baku zeolit dengan perbandingan $\mathrm{Si} / \mathrm{Al}$ kecil $<2$. Dengan komposisi awal ini, zeolit yang akan terbentuk akan lebih mengarah pada zeolit dengan kemampuan penukar ion yang cukup baik.

Tabel 1 Data karakterisasi bottom ash dan zeolit sintetis dengan menggunakan EDS

\begin{tabular}{|c|c|c|c|c|}
\hline \multirow{2}{*}{ Unsur } & \multicolumn{4}{|c|}{$\%$ Berat } \\
\cline { 2 - 5 } & Bottom ash & A1T & A2T & A3T \\
\hline $\mathrm{C}$ & 25,19 & 26,86 & 18,87 & 17,57 \\
\hline $\mathrm{N}$ & 25,28 & 23,25 & 22,92 & 25,92 \\
\hline $\mathrm{O}$ & 24,08 & 22,8 & 26,03 & 25,19 \\
\hline $\mathrm{Na}$ & 0,14 & 4,65 & 6,01 & 6,95 \\
\hline $\mathrm{Mg}$ & 0,27 & - & - & - \\
\hline $\mathrm{Al}$ & 8,68 & 8,67 & 9,52 & 9,56 \\
\hline $\mathrm{Si}$ & 13,25 & 11,08 & 12,58 & 11,78 \\
\hline $\mathrm{Cl}$ & 0,09 & - & 0,51 & 0,34 \\
\hline $\mathrm{K}$ & 0,82 & 0,45 & 0,52 & 0,42 \\
\hline $\mathrm{Ca}$ & 2,2 & 0,97 & 1,41 & 0,94 \\
\hline $\mathrm{Fe}$ & - & 1,26 & 1,63 & 1,35 \\
\hline
\end{tabular}

Jika dilihat dari rasio $\mathrm{Si} / \mathrm{Al}$, zeolit sintetis yang terbentuk merupakan zeolit dengan kadar $\mathrm{Si} / \mathrm{A} 1$ rendah dengan nilai $<2$. Rasio $\mathrm{Si} / \mathrm{A} 1$ zeolit sintetis $\mathrm{A} 1 \mathrm{~T}=1,28, \mathrm{~A} 2 \mathrm{~T}=1,32$, dan $\mathrm{A} 3 \mathrm{~T}=1,23$. Dari rasio $\mathrm{Si} / \mathrm{Al}$, zeolit yang terbentuk yaitu zeolit $\mathrm{Na}-\mathrm{X}$ dan Na-P karena kedua zeolit tersebut memiliki rasio $\mathrm{Si} / \mathrm{Al}<2$ yang memperkuat hasil karakterisasi menggunakan XRD dan SEM dengan didapatkannya zeolit Na-X dan Na-P. Kandungan mineral lain yang terkandung dalam sampel zeolit sintetis memiliki jumlah lebih kecil yang diharapkan akan memperbaiki sifat konduktivitas listrik dari zeolit.

Penggunaan air laut memberikan peranan dalam peningkatan jumlah unsur $\mathrm{Na}$ karena kerangka zeolit merupakan kerangka tiga dimensi yang dibentuk oleh $\mathrm{SiO}_{4}$ dan $\mathrm{AlO}_{4}$. Ion $\mathrm{Al}$ bervalensi 3+, ketika berikatan dengan $\mathrm{Si}$ akan menyebabkan kerangka menjadi bermuatan negatif sehingga dibutuhkan kation untuk menyeimbangkan muatannya. Oleh sebab itu, kation $\mathrm{Na}^{+}$memberikan peranan penting dalam penyeimbang kerangka yang dimanfaatkan sebagai penukar ion.

Komposisi unsur Na paling banyak terdapat pada zeolit sintetis A3T disebabkan karena air laut di tepi pantai memiliki unsur $\mathrm{Na}$ yang cukup besar sehingga mempengaruhi unsur $\mathrm{Na}$ dari zeolit sintetis yang terbentuk sedangkan pada zeolit sintetis A1T dan A2T terjadi penurunan komposisi unsur $\mathrm{Na}$.

\subsection{Nilai Konduktivitas Listrik Zeolit Sintetis}

Karakterisasi sifat listrik (konduktivitas listrik) didapatkan dari pengukuran resistansi dengan menggunakan alat LCR-meter model TH2820. Hasil pengukuran resistansi hingga didapatkan nilai konduktivitas listrik dapat dilihat pada Tabel 2. Dari Tabel 2 terlihat bahwa nilai konduktivitas listrik $(\sigma)$ berkisar dari $1,059 \times 10^{-6}-3,040 \times 10^{-6} \mathrm{~S} / \mathrm{cm}$. Nilai konduktivitas ini berada pada rentang konduktivitas semikonduktor. Secara 
keseluruhan, sampel A3T memiliki nilai konduktivitas yang lebih tinggi dibandingkan sampel A1T dan A2T. Konduktivitas listrik zeolit sintetis dengan nilai tertinggi terdapat pada sampel A3T dengan nilai 3,040 x $10^{-6} \mathrm{~S} / \mathrm{cm}$ pada frekuensi $1000 \mathrm{~Hz}$.

Tabel 2 Hasil Karakterisasi konduktivitas listrik zeolit sintetis

\begin{tabular}{|c|c|c|c|c|c|c|}
\hline No. & Zeolit & $\mathrm{f}(\mathrm{Hz})$ & $\mathrm{A}\left(\mathrm{mm}^{2}\right)$ & $\mathrm{L}(\mathrm{mm})$ & $\mathrm{R}(\mathrm{k} \Omega)$ & $\sigma(\mathrm{S} / \mathrm{cm})$ \\
\hline \multirow{3}{*}{1.} & \multirow{3}{*}{ A1T } & 100 & 121,677 & 1,400 & 108,632 & $1,059 \times 10^{-6}$ \\
\hline & & 120 & 121,677 & 1,400 & 105,278 & $1,092 \times 10^{-6}$ \\
\hline & & 1000 & 121,677 & 1,400 & 40,394 & $2,848 \times 10^{-6}$ \\
\hline & & & & & & \\
\hline \multirow{3}{*}{2.} & \multirow{3}{*}{$\mathrm{A} 2 \mathrm{~T}$} & 100 & 121,677 & 1,375 & 92,098 & $1,226 \times 10^{-6}$ \\
\hline & & 120 & 121,677 & 1,375 & 84,246 & $1,341 \times 10^{-6}$ \\
\hline & & 1000 & 121,677 & 1,375 & 38,812 & $2,911 \times 10^{-6}$ \\
\hline & & & & & & \\
\hline \multirow{3}{*}{3.} & \multirow{3}{*}{ A3T } & 100 & 121,677 & 1,325 & 84,591 & $1,287 \times 10^{-6}$ \\
\hline & & 120 & 121,677 & 1,325 & 78,465 & $1,387 \times 10^{-6}$ \\
\hline & & 1000 & 121,677 & 1,325 & 35,812 & $3,040 \times 10^{-6}$ \\
\hline
\end{tabular}

Jika dilihat dari segi kristalinitas zeolit sintetis, semakin tinggi derajat kristalinitasnya, akan mengakibatkan naiknya nilai konduktivitas (Ertugrul, 2007). Intensitas utama semua sampel berasal dari zeolit Na-X yang merupakan tipe zeolit dengan rasio $\mathrm{Si} / \mathrm{Al}<$ 2. Hal ini ditunjukkan dengan nilai konduktivitas yang berada pada rentang yang sama. Sampel A3T merupakan zeolit sintetis dengan tingkat kristalinitas yang terbaik yang terlihat pada intensitas puncak tertinggi dibandingkan sampel lainnya. Perbedaan konduktivitas lebih disebabkan oleh homogenitas serta tingkat kristalinitas masingmasing sampel yang berbeda, sebagaimana tergambar pada hasil pola XRD (Gambar 1) dan foto SEM (Gambar 2).

Konduktivitas listrik pada sampel A3T dipengaruhi oleh media kristalisasi yang digunakan yaitu air laut di tepi pantai yang menunjukkan berlimpahnya unsur $\mathrm{Na}$ sehingga didapatkan krital zeolit yang lebih murni daripada sampel A2T dan A1T. Penggunaan air laut sebagai media kristalisasi mampu meningkatkan kristalinitas serta homogenitas zeolit yang berpengaruh juga pada konduktivitas zeolit.

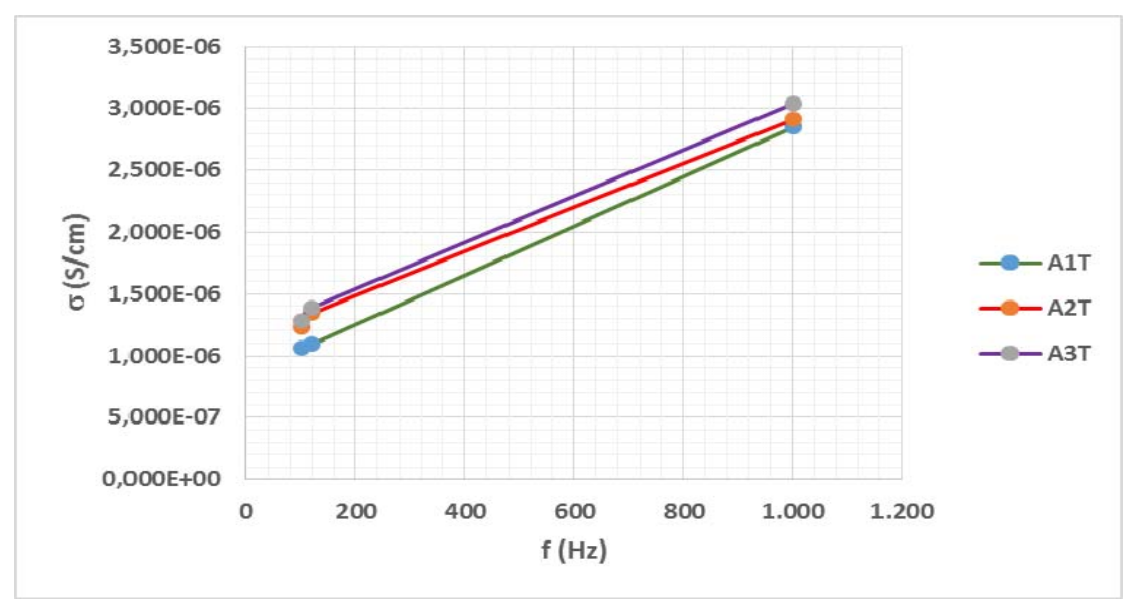

Gambar 3 Pengaruh frekuensi terhadap konduktivitas zeolit sintetis 
Penggunaan tegangan AC dengan frekuensi $100 \mathrm{~Hz}, 120 \mathrm{~Hz}$, dan $1000 \mathrm{~Hz}$ memberikan pengaruh pada aktivitas pembawa muatan yang berada pada sampel. Hal ini ditunjukkan dari bervariasinya nilai konduktivitas yang terlihat pada Gambar 3. Nilai konduktivitas meningkat seiring dengan semakin tingginya frekuensi yang digunakan.

Dari Gambar 3 terlihat bahwa sampel A3T memiliki nilai konduktivitas yang lebih besar dibandingkan A2T dan A1T untuk setiap frekuensinya. Ini menunjukkan aktivitas pembawa muatan pada ketiga sampel memiliki kecenderungan yang sama. Tingginya konduktivitas pada sampel A3T, sebagaimana telah disampaikan sebelumnya, disebabkan berbagai faktor, antara lain : homogenitas, kristalinitas serta struktur permukaan yang mempengaruhi aktivitas pembawa muatan (Smallman dan Bishop, 2000; Vijaya dan Rangarajan, 2003). Sampel A1T memiliki nilai konduktivitas paling rendah dikarenakan tingkat kristalinitas yang masih kurang baik dan masih banyak terdapat kuarsa dan hidroksisodalit yang menghambat mobilitas pembawa muatan pada sampel. Jadi, pada sampel zeolit sintetis yang dihasilkan, kristalinitas dan homogenitas dari sampel mempengaruhi nilai konduktivitas ke nilai yang lebih tinggi.

\section{KESIMPULAN}

Unsur yang terdapat pada air laut memberikan pengaruh penting dalam sintesis zeolit. Air laut yang diambil dari tepi pantai menghasilkan zeolit dengan tingkat kristalinitas yang lebih baik. Kadar mineral pada media kristalisasi yang digunakan mempengaruhi kristalinitas zeolit, zeolit yang didapatkan mayoritas adalah zeolit Na-X (hasil XRD). Struktur permukaan zeolit mayoritas berbentuk kubik yang merupakan zeolit Na-X, akan tetapi zeolit sintetis dengan media kristalisasi air laut dari tepi pantai memberikan bentuk zeolit lebih homogen daripada menggunakan media kristalisasi air laut dari muara dan akuades (hasil SEM). Zeolit sintetis yang dihasilkan memiliki rasio Si/Al $<2$ (hasil EDS). Hasil ini memperkuat hasil karakterisasi XRD dan SEM yang memberikan hasil dari zeolit sintetis yaitu $\mathrm{Na}-\mathrm{X}$ karena zeolit $\mathrm{Na}-\mathrm{X}$ memiliki rasio $\mathrm{Si} / \mathrm{Al}<2$ yang memiliki sifat sebagai penukar kation yang baik. Zeolit sintetis berdasarkan nilai konduktivitas listrik berada pada rentang material semikonduktor. Zeolit sintetis menggunakan media kristalisasi air laut dari tepi pantai Padang memiliki nilai konduktivitas listrik lebih tinggi dibandingkan sampel zeolit sintetis dengan media kristalisasi air laut dari muara Padang dan akuades. Konduktivitas listrik zeolit yang didapatkan yaitu bernilai $1,287 \times 10^{-6}$ $3,040 \times 10^{-6} \mathrm{~S} / \mathrm{cm}$.

\section{DAFTAR PUSTAKA}

1. Anggoro, dkk., 2007, Pengaruh Kandungan Silikat dan Aluminat dalam Pembuatan Zeolit sintetis Y dari Abu Sekam Padi, Jurnal Nasional Teknik Kimia UNDIP, UNDIP, hal 1-6.

2. Aurbach, S.M., Carrado, K.A., dan Dutta, P.K., 2003, Zeolite Sains Science and Technology, ed. 10, Marcel Dekker, Inc., United State of America.

3. Belviso, C., Francesco, C., Antinio, L., and Saverio, F., 2009, Zeolites synthesis from Coal Fly Ash at Low Temperatures Using Seawater for Crystalization, CCGP journal, Vol. 1, UK CAER and ACAA, hal 8-13.

4. Ertugrul and Alime, 2007, Dielectric Behavior of the Catalyst Zeolite NaY, Turkis Journal of Chemistry, Tubitak, hal 523-530.

5. Fatiha, W.Y., 2013, Sintesis Zeolit dari Fly Ash Batubara ombilin pada Temperatur Rendah dengan Menggunakan Air Laut, Skripsi, FMIPA UNAND, Padang.

6. Jumaeri, W.A. dan W.T.P. Lestari., 2007, Preparasi dan Karakterisasi Zeolit dari Abu Layang Batubara Secara Alkali Hidrotermal, Jurnal Reaktor, Vol. 11, No. 1, UNES, hal 38-44. 
7. Kalogeras, I. M. and Dova, A.V., 1998, Electrical Properties of Zeolitic Catalyst, Defect and Diffusion Forum, Vol. 164, Scitec Publications, hal 1-36.

8. Li, X. and Dutta, P.K., 2010, Interaction of Dimethylmethylphosphonate with zeolite Y : Impedance Based Sensor for Detecting Nerve Agent Simulants, The Journal of Phisical Chemistry C, Vol. 144, No. 17, ACS Publications, hal 7986-7993.

9. Londar, E., Hamzah, F., dan Nurul, W., 2010, Pengaruh Karbon Terhadap Pembentukan Zeolit dari Abu Dasar dengan Metode Hidrotermal langsung, Jurnal Kimia ITS, FMIPA ITS, hal 1-13.

10. Smallman, R. E. dan Bishop, R. J., 2000, Metalurgi Fisik Modern dan Rekayasa Material, Ed. 6, Erlangga, Jakarta.

11. Sholichah, F., Arnelli, dan Ahmad, S., 2013, Pengaruh Waktu Hidrotermal pada Sintesis Zeolit dari Abu Sekam Padi serta Aplikasinya sebagai Builder Deterjen, Jurnal Chem Info, Vol. 1, No. 1, FMIPA UNDIP, hal 121-129.

12. Sunardi, Taufiqur, R., Edi, M., dan Rini, R., 2007, Pengaruh Waktu Refluks dengan $\mathrm{NaOH}$ Terhadap Konversi Abu Layang Batubara Menjadi Zeolit, Jurnal Sains dan Terapan Kimia, Vol. 1, No. 2, UNLAM, hal 83-92.

13. Trivana, L., 2013, Sintesis Zeolit X dan Nanokomposit Zeolit $\mathrm{TiO}_{2}$ dari Kaolin dengan Sekan Padi sebagai Sumber Silika, Skripsi, FMIPA ITP, Bogor.

14. Vijaya, M.S. and Rangarajan. G., 2003, Materials Science, Tata McGraw-Hill Publising Company Limited, New Delhi.

15. Widiawati, 2005, Sintesis Zeolit dari Abu Ketel Asal Pg. Tasik Madu : ragam Zeolit Pada Berbagai Konsentrasi Natrium Aluminat, Skripsi, FMIPA Universitas Sebelas Maret, Surakarta.

16. Yang, R.T., 2003, Absorbents: Fundamental and Aplications, Ed. 10, Jhon Wiley and Sons. Inc, New Jersey.

17. Yunica, F., 2013, Sintesis dan Karakterisasi Sifat Listrik PANi : Zeolit dari Limbah Botton Ash, Skripsi, FMIPA UNAND, Padang.

18. Yu, Y., LI Xiaoliang., ZOU, Xiaolan., and ZHU, Xiaobin., 2014, Effect of Seawater Salinity on the Synthesis of Zeolites from Coal Fly Ash, Frontiers of Environment Science \& Engineering, Vol. 8, No.1, Higher Education Press and Springer, hal 5461. 